\title{
Preparation of High Effective Flocculant for High Density Waste Drilling Mud
}

\author{
Fanghui Wang, Jing Zou, Hong Zhu*, Kefei Han, Jiantao Fan
}

School of Science, Beijing University of Chemical and Technology, Beijing, China.

Email: zhuho128@126.com

Received February $2^{\text {nd }}, 2010$; revised May $4^{\text {th }}, 2010$; accepted May $5^{\text {th }}, 2010$.

\begin{abstract}
To satisfy the requirement on the separation of solid and liquid in waste drilling mud, prepare a high effective flocculant for high density waste drilling mud used starch, 2-Trimethylammonium ethyl methacrylate chloride (DMC) and acrylamide $(A M)$. The result showed that when the ratio of starch, DMC and AM was 2:1:3, the weight of initiator (potassium persulfate) was $0.2 \%$ of the AM, reaction temperature was $65^{\circ} \mathrm{C}$ and reaction time was 5 h, the performance of product was the best. The water content in filter cake was $27.6 \%$ after the waste drilling mud disposed by the optimization flocculant. The flocculent effect of optimization flocculant was superior to that of other flocculant in market.
\end{abstract}

Keywords: High Density, Waste Drilling Mud, Dispose, Cation

\section{Introduction}

The waste drilling mud and drilling wastewater were the inevitable industrial waste while Oil and Gas Exploration Drilling. They has become one of the most severe pollution sources, whose effect on environment has been concerned gradually [1-3].There were many methods [4-7] to dispose the waste drilling mud and drilling wastewater, such as, Gravity Separation, Impact, Baffle, or Spray Separation, Parallel-Plate and Thin-Film Separation and Vacuum Separation. The Solid-Liquid Separation has such advantages as large capacity, simple operation and using a few equipments [8], it was the most important and Widely Application method. At deep well drilling, the component of waste drilling mud was more and more complexity, the density of waste drilling mud was higher, and the waste drilling mud treatment was more harder [9]. The flocculant in market has not deal with the high density waste drilling mud. So a new starch-based cation copolymer flocculant for high density waste drilling mud was prepared.

\section{Methods}

\subsection{Agent}

Edible corn starch, 2-Trimethylammonium ethyl methacrylate chloride (CP), acrylamide (A.R), potassium persulfate (A.R), sodium hydroxide (A.R).

High density waste drilling mud, the density was 1.639 $\mathrm{g} / \mathrm{mL}$ and the Solid content was $56.72 \%$.

\subsection{Synthesis of Starch-Based Cation Coploymer Flocculant}

Add some deionized water, corn starch and sodium hydroxide into a three-neck flask with stirrer. Heat the system to $70^{\circ} \mathrm{C}$ and stir until starch dissolved completely (about $30 \mathrm{~min}$ ), then cool the system to room temperature and removal of oxygen dissolved in the solution by blowing continuously nitrogen. After add some AM and DMC into above system, add the potassium persulfate solution drop by drop. Keep the system react for a certain time at a given temperature to gain product.

\subsection{Flocculent Treatment}

Add some gel breaker to some waste drilling mud, then add some flocculant to above system and stir, centrifugal separation $(3500 \mathrm{r} / \mathrm{min})$ for $10 \mathrm{~min}$. Weight the quality of filter cake (m1) and soild phase (m2) after baking, gain the water content in filter cake by the formula as follows: the water content in filter cake $=(\mathrm{m} 1-\mathrm{m} 2) / \mathrm{m} 1$.

\section{Result and Discussion}

\subsection{Preparing Conditions of Starch-Based Cation Copolymer Flocculant}

\subsubsection{Appropriate Weight Ratio of AM and Starch}

The amount of starch was $3 \mathrm{~g}$, DMC dosage was $1 \mathrm{~mL}$, $\mathrm{pH}=7$, the reaction temperature was $70^{\circ} \mathrm{C}$, reaction time was $3 \mathrm{~h}$, the amount of acrylamide was respectively $3 \mathrm{~g}$, $6 \mathrm{~g}, 9 \mathrm{~g}, 12 \mathrm{~g}$, the amount of potassium persulfate was 
$0.2 \%$ of the quality of acrylamide. The flocculent effect is shown in Figure 1.

Figure 1 showed when $\mathrm{m}(\mathrm{AM}) / \mathrm{m}(\mathrm{starch})=3$, the water content in filter cake was the minimum $(32.3 \%)$. When the $\mathrm{m}(\mathrm{AM}) / \mathrm{m}$ (starch) above 3 , the lesser quality of starch made the active sites for graft reaction decrease, so the molecular weight of copolymer diminished. The Low Molecular Weight copolymer could not link tightly with solid matter in waste drilling mud, so the flocculation effect was not good.

\subsubsection{Appropriate Dosage of DMC}

The starch quality was $3 \mathrm{~g}$, the quality of acrylamide was $9 \mathrm{~g}, \mathrm{pH}=7$, the reaction temperature was $70^{\circ} \mathrm{C}$, reaction time was $3 \mathrm{~h}$, the amount of potassium persulfate was $0.2 \%$ of the quality of acrylamide, DMC dosage respectively was $1 \mathrm{~mL}, 2 \mathrm{~mL}, 3 \mathrm{~mL}, 4 \mathrm{~mL}$. Study the effect of DMC dosage on the water content in filter cake (Figure 2).

Figure 2 showed when the DMC dosage was $2 \mathrm{ml}$, the water content in filter cake was the lowest. Increasing the dosage of DMC make the cationic degree of copolymer increase. The clay in waste drilling mud charged negative, so the higher of the cationic degree of copolymer was,

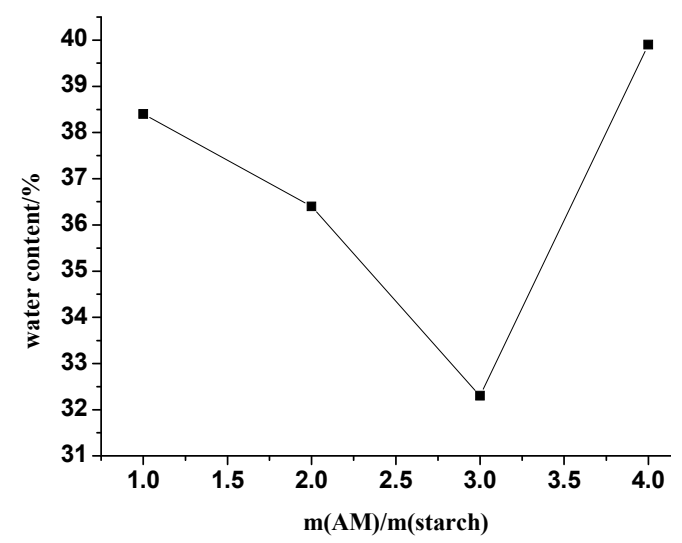

Figure 1. The effect of $\mathrm{m}(\mathrm{AM}) / \mathrm{m}(\mathrm{starch})$ on water content in filter cake

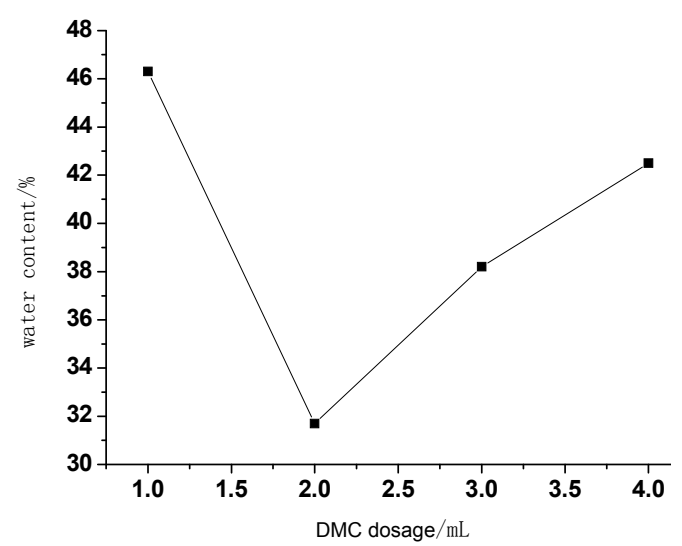

Figure 2. The effect of DMC dosage on water content in filter cake the more the negative charge neutralized, so the solid matter in waste drilling mud was more easier to separate from waste drilling mud. But when the DMC dosage was greater than $2 \mathrm{~mL}$, the water content in filter cake increased. The reason maybe as follows:

1) Impact of $\mathrm{Cl}^{-}$: The initiator was $\mathrm{K}_{2} \mathrm{~S}_{2} \mathrm{O}_{8}, \mathrm{Cl}^{-}$can react with $\mathrm{S}_{2} \mathrm{O}_{8}{ }^{2-}$ to form $\mathrm{Cl}_{2}, \mathrm{Cl}$ atom can act as a chain termination agent, so that the molecular weight of copolymer decreased.

2) Steric Hindrance Effect: DMC with Steric Hindrance reduce the probability of collision between DMC monomer and chain free radical.

Above two factor increase the difficult of Polymerization between DMC and starch and AM, so the flocculation effect was not good.

\subsubsection{Appropriate Dosage of Initiator}

The amount of starch was $3 \mathrm{~g}$, DMC amount was $2 \mathrm{~mL}$, the amount of acrylamide was $9 \mathrm{~g}, \mathrm{pH}=7$, the reaction temperature was $70^{\circ} \mathrm{C}$, reaction time was $3 \mathrm{~h}$. The amount of potassium persulfate was respectively $0.1 \%, 0.2 \%$, $0.3 \%, 0.4 \%, 0.5 \%$ of the quality of acrylamide. The flocculent effect is shown in Figure 3.

From Figure 3 we can see that when the potassium persulfate dosage was $0.3 \%$, the water content in filter cake was the lowest. Because when the amount of potassium persulfate increased, the concentration of free radicals increase, grafting reaction rate accelerated, graft product molecular weight was larger. But when the quality of potassium persulfate was more than $0.3 \%$ that of acrylamide monomer, the water content of filter cake actually increased. The increasing concentration of potassium persulfate caused homopolymerization reaction probability of monomer increase and the termination of free radicals also increase, so the copolymer molecular weight was not big enough and the water content in filter also increased.

\subsubsection{Reaction Time}

The amount of starch was $3 \mathrm{~g}$, DMC amount was $2 \mathrm{~mL}$,

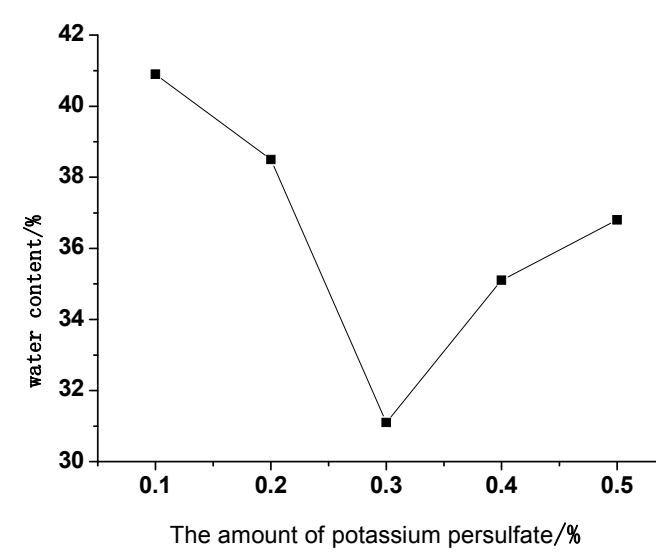

Figure 3. The effect of potassium persulfate dosage on water content in filter cake 
the amount of acrylamide was $9 \mathrm{~g}, \mathrm{pH}=7$, the amount of potassium persulfate was $0.3 \%$ of the quality of acrylamide, reaction temperature was $70^{\circ} \mathrm{C}$, the reaction time was respectively $3 \mathrm{~h}, 4 \mathrm{~h}, 5 \mathrm{~h}, 6 \mathrm{~h}, 7 \mathrm{~h}$. The flocculent effect is shown in Figure 4.

As can be seen from Figure 4, the best reaction time was $4 \mathrm{~h}$, this was because early in the reaction system, the active center of grafting reaction was more, the reaction rate was quick. But when the reaction time was more than $4 \mathrm{~h}$, the number of grafting points decreased, which made grafting reaction rate slow down, so the grafting yield had fallen and the water content in filter cake correspondingly increased.

\subsubsection{Reaction Temperature}

The amount of starch was $3 \mathrm{~g}$, DMC amount was $2 \mathrm{~mL}$, the amount of acrylamide was $9 \mathrm{~g}, \mathrm{pH}=7$, the amount of potassium persulfate was $0.3 \%$ of the quality of acrylamide, reaction time was $4 \mathrm{~h}$, the reaction temperature was respectively $50^{\circ} \mathrm{C}, 55^{\circ} \mathrm{C}, 60^{\circ} \mathrm{C}, 65^{\circ} \mathrm{C}, 70^{\circ} \mathrm{C}, 75^{\circ} \mathrm{C}$. The flocculent effect is shown in Figure 5.

The reaction temperature at $65^{\circ} \mathrm{C}$, the water content in filter cake was the lowest. Because temperature rising within a certain range can increases the degree of starch

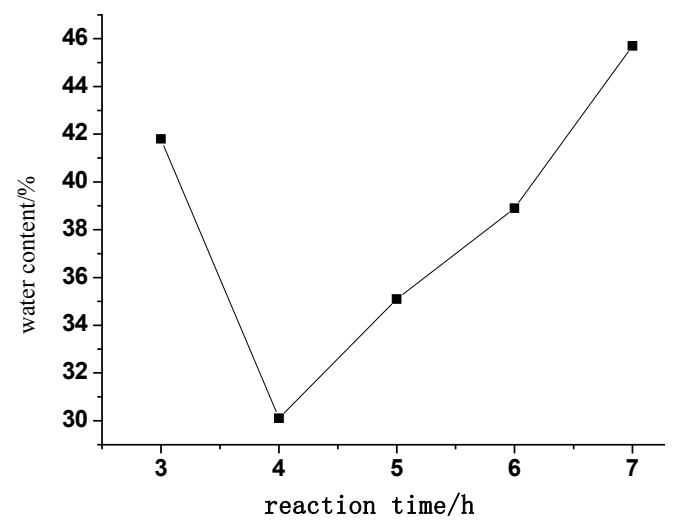

Figure 4. The effect of reaction time on water content in filter cake

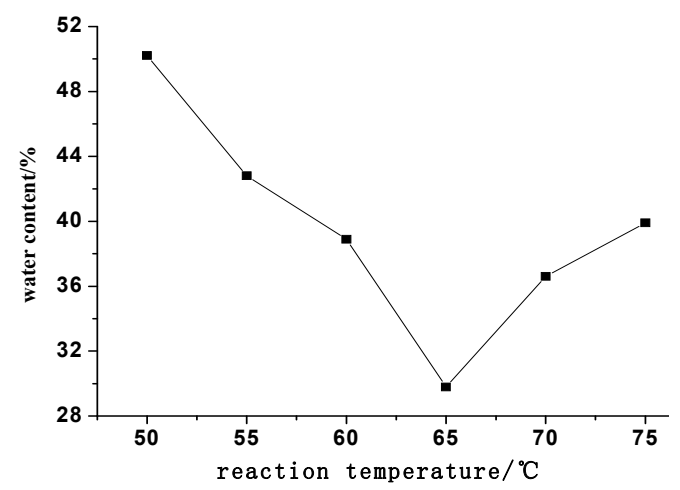

Figure 5. The effect of reaction temperature on water content in filter cake swelling in water, thus ensure the reaction in the homogeneous and be propitious to disperse initiator and monomer. When the temperature rose exceeds $65^{\circ} \mathrm{C}$, the chain termination reaction rate increased, which lead to lower grafting yield, so the water content in filter cake was higher.

\subsection{Analysis of FTIR}

Figure 6 and Figure 7 are respectively FTIR spectra of starch and copolymer flocculant. As can be seen from the Figure 6, the peak of IR spectra of $-\mathrm{OH}$ symmetric stretching vibration in starch glucose unit appeared at $3440 \mathrm{~cm}^{-1}$ and $3442 \mathrm{~cm}^{-1}$. From Figure 7, we can know the peak of IR spectra of $\mathrm{C}=\mathrm{O}$ stretching vibration and $-\mathrm{NH}_{2},-\mathrm{CH}_{2}$ stretching vibration in copolymer flocculant appeared respectively at $1670 \mathrm{~cm}^{-1}, 3198 \mathrm{~cm}^{-1}, 1027 \mathrm{~cm}^{-1}$. There be should have two absorption peak at $3198 \mathrm{~cm}^{-1}$, but it overlapped with the strong broad hydroxyl peak of starch, so there was only a single peak. The absorption peak appeared at $1618 \mathrm{~cm}^{-1}$ was the $-\mathrm{NH}_{2}$ bending vibration characteristic peaks. So, there must have some structural units of AM and DMC in the starch- based cation copolymer flocculant.

\subsection{Flocculent Effect}

From Figure 8 we can see that adding the same amount of flocculant, the flocculent effect of organic flocculants was better than that of inorganic coagulant, but the results are not satisfactory, the water content in filter cake

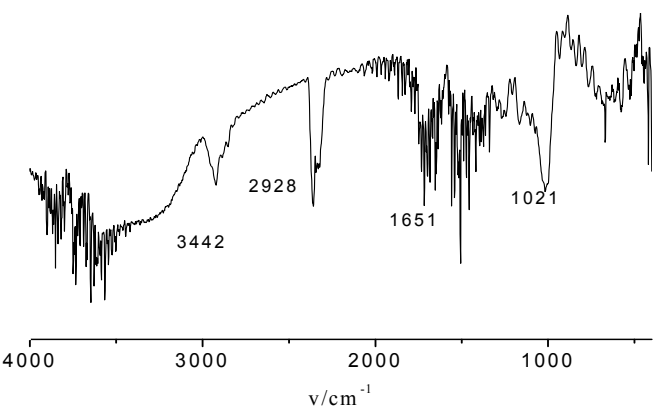

Figure 6. FTIR spectra of corn starch

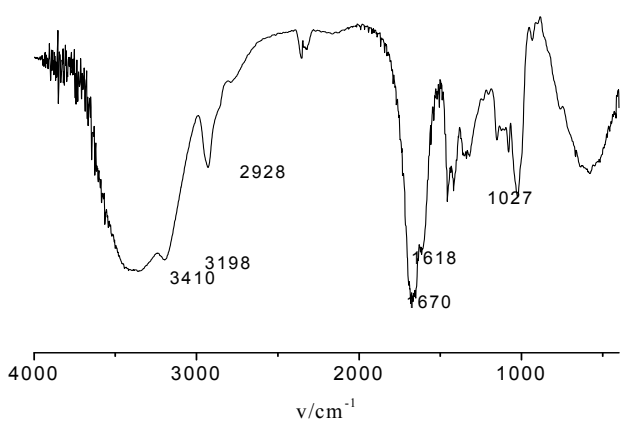

Figure 7. FTIR spectra of starch-based cation copolymer flocculant 


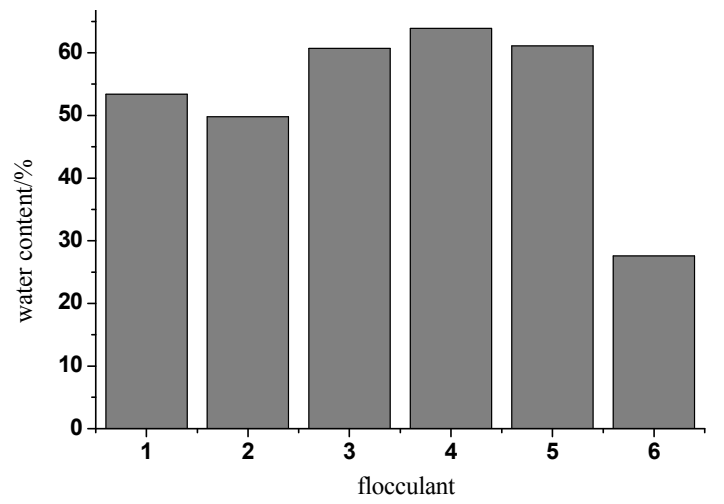

1-Non-ionic polyacrylamide; 2 - Cationic polyacrylamide; 3-Anionic polyacrylamide; 4-Polymerization ferric sulphate; 5-Polymerization aluminum sulfate; 6 - Starch-based cation copolymer

Figure 8. Floccuent effect of some flocculant

was more than 50\%. From Figure 8, the flocculent effect of the starch-based cation copolymer flocculant was significantly better than that of the other coagulant in market, water content of waste drilling mud after treated rate was $27.6 \%$.

\section{Conclusions}

Starch, 2-Trimethylammonium ethyl methacrylate chloride (DMC) and acrylamide (AM) used as raw material and potassium persulfate as initiator to prepare a starch-based cation copolymer flocculant. For highdensity waste drilling mud, the flocculent effect of the starch-based cation copolymer flocculant flocculation was significantly better than that of the other coagulant in market.

\section{Acknowledgements}

This paper is supported by National Hi-Tech Research and Development Program of China (863 Program) (2008BAC43B02).

\section{REFERENCES}

[1] M. J. Yang, W. L. Liang, Q. R. Jin, X. H. Wu and G. N. $\mathrm{Yu}$, "Study on Comprehensive Treatment Technique about Waste Drilling Mud," Mineral Petrology, in Chinese, Vol. 23, No. 1, 2003, pp. 109-112.

[2] M. O. Benka and A. Olumagin, "Effects of Waste Drilling Fluid on Bacterial Isolates from a Mangrove Swamp Oilfield Location in the Niger Delta of Nigeria," Bioresource Technology, Vol. 55, No. 3, 1996, pp. 175-179.

[3] S. Rehan and H. Tahir, "A Fuzzy-Based Methodology for an Aggregative Environmental Risk Assessment: A Case Study of Drilling Waste," Environmental Modelling \& Software, Vol. 20, No. 1, 2005, pp. 33-46.

[4] C. G. Street and S. E. Guigard, "Treatment of Oil-Based Drilling Waste Using Supercritical Carbon Dioxide," Journal of Canadian Petroleum Technology, Vol. 48, No. 6, 2009, pp. 26-29.

[5] H. Shang, S. Kingman, C. Snape and J. Robinson, "A New Technology of Microwave Treatment of Oil Contaminated Drilling Waste in a Single Mode Cavity," Acta Petrolei Sinica (Petroleum Processing Section), in Chinese, Vol. 25, No. 3, 2009, pp. 358-362.

[6] J. A. Veil, "Drilling Waste Management: Past, Present, and Future," Proceedings of SPE Annual Technical Conference and Exhibition, San Antonio, 29 September-2 October 2002, pp. 545-551.

[7] ASME Shale Shaker Committee, "Drilling Fluids Processing Handbook," Gulf Professional Publishing, Burlington, 2005.

[8] Y. Xiao, R. S. Wang and H. Deng, "Treatment of Chemically Enhanced Sold-Liquid Separation for Waste Drilling Fluid," China Environmental Science, Vol. 20, No. 5, 2000 , pp. 453-456.

[9] G. Li, M. Zhu and J. L. Qian, "Lab Experiments into Solid-Liquid Separation of Waste High Density Drilling Liquid," Petroleum Drilling Techniques, in Chinese, Vol. 26, No. 1, 1998, pp. 21-22. 